\title{
Studies in Manuscript Cultures
}

Edited by

Michael Friedrich

Harunaga Isaacson

Jörg B. Quenzer

Volume 11 


\section{Manuscripts and Archives}

Comparative Views on Record-Keeping

Edited by

Alessandro Bausi, Christian Brockmann, Michael Friedrich, Sabine Kienitz 


\title{
Cécile Michel
}

\section{Constitution, Contents, Filing and Use of Private Archives: The Case of Old Assyrian Archives (nineteenth century BCE)}

\begin{abstract}
The archives of the ancient Near East do not correspond to a collection of cuneiform tablets preserved for their historical value, but more to a set of texts all kept in the same place, concerning the same individuals or dealing with the same topics. They were accumulated as long as they were considered to be useful. Besides uncovering official archives used by large organisations (palaces and temples), archaeologists have also excavated many private archives; these belonged to individuals and were found in their houses. Assyrian merchants' archives unearthed at Kültepe (the ancient town of Kaneš) in Central Anatolia represent the first important group of private cuneiform archives and they mainly date back to the nineteenth century BCE. These archives consist of letters, legal texts and memoranda. They were arranged on shelves or inside labelled containers using a classification system that gives us hints about the use merchants made of their archives.
\end{abstract}

For more than three millennia, populations of the ancient Near East used cuneiform script to write down all types of texts, whatever the purpose, be it administrative, official, scholarly or private, for example. Cuneiform signs could be engraved on stone, metal or wax spread on wooden or (in exceptional cases) ivory tablets. However, the vast majority of texts in cuneiform script were impressed on fresh clay. Unbaked clay tablets were the standard vehicle of writing; clay was one of the most durable materials of antiquity. As a matter of fact, hundreds of thousands of clay tablets have been unearthed at sites all over the Near East, from central Anatolia to Iran, and to Egypt and Bahrain.

Found in palaces, temples and private houses and arranged in specific rooms or areas of buildings, some groups of cuneiform tablets have been referred to as 'libraries', while the great majority of them are now known as 'archives'. The archives' content varies according to the type of building in which they were found. This paper focuses on private archives that once belonged to Assyrian merchants and were unearthed in their houses in the lower town of Kaneš (modern-day Kültepe in Central Anatolia). The content of these archives gives us information about their historical context and allows us to study their constitution. As an example, the analysis of the tablets excavated in 1993 has provided us with data about their owners, the filing systems employed for tablets and what such archives were used for. 


\section{Some definitions}

The words 'archive' and 'archives' are most commonly used by Assyriologists to refer to the groups of inscribed clay tablets found at numerous archaeological sites in the Near East. Several series titles with volumes of text publications and editions include these words, such as 'Archives Royales de Mari', 'Old Assyrian Archives' and 'State Archives of Assyria'. A Rencontre Assyriologique Internationale, the annual congress of Assyriology, was dedicated to Cuneiform Archives and Libraries in 1983 (Veenhof 1986), and this was also part of the title of a study by Olof Pedersén (1998). Two recent collective thematic volumes deal more specifically with archives: Archives and Archival Traditions (Brosius 2003) and Archives and Archival Documents (Faraguna 2013). ${ }^{1}$

\subsection{Libraries and archives in the ancient Near East}

Studying the groups of tablets excavated in the city of Aššur, Olof Pedersén (1986, 20-21) proposed the following distinction:

Each group of interrelated texts is classified [here] either as a library or an archive. 'Library' describes a group of literary texts in the widest sense of the word, including for example lexical texts. 'Archive' describes a group of texts of administrative, economic, juridical and similar types, including letters. The occurrence of a few texts of the opposite type has not led to a classification change from library to archive or vice versa, but when there are any considerable number of texts of the opposite categories, the collection is described as a library with [an] archive.

Such a definition has been further developed by $\mathrm{Ph}$. Clancier in his study of first-millennium libraries in Babylonia; he distinguishes three groups of texts here (2009, 16-17):

1. Les archives. Il s'agit de fonds conservant des textes de la pratique qui se composent de documents légaux (contrats par exemple), de textes administratifs, de correspondance, etc.

2. Les fonds de manuscrits et les fonds d'archives. Ce sont des collections mixtes de documents de la pratique et de tablettes littéraires et savantes [...]..$^{2}$

3. Les bibliothèques. Ce sont des fonds de tablettes littéraires et savantes.

1 The first scholar to highlight the importance of archives and archival practices in the ancient Near East was E. M. Posner (1972); see the chapter by D. Schenk in this volume.

2 Here the author refers to a study by G. Ouy ('Les Bibliothèques', in L'histoire et ses méthodes, Encyclopédie de la Pléïade XI, Paris 1973, 1061-1106, esp. 1093) in which he defines 'fonds de manuscrits' as follows: 'un fonds de manuscrits est l'ensemble des livres ou documents manuscrits intéressant l'histoire intellectuelle - ensemble entendu au sens large - de la collectivité, de la famille ou de l'individu qui les a copiés, fait copier, reçus en hommage ou réunis [...]. La différence la plus importante qui oppose fonds de manuscrits et fonds d'archives [...] est liée au caractère propre du livre manuscrit.' 
It is common among Assyriologists to use the term 'library' when referring to groups of texts dealing with divination, medicine, religion, technical matters, science, literature and words (lexical lists). Such texts were kept in the houses of priests, diviners or other scholars, but more often in palaces and temples. Palatial libraries had a special status; the best known and documented of these is the library of Aššurbanipal at Nineveh (seventh century BCE), which was truly encyclopaedic. The king sent letters to all the high officials of his empire and even to Babylonia asking for rare tablets:

Search out for me [...] any texts that might be needed in the palace, as many as there are, also rare tablets that are known to you but do not exist in Assyria, and send them to me. ${ }^{3}$

Tablets from the royal library of Nineveh form the largest known collection of scholarly cuneiform texts, amounting to more than 20,000 tablets, which are now preserved in the British Museum.

The other groups of tablets, which make up the majority of tablets discovered in the Near East, are called 'archives'. These correspond to collections of texts kept together in the same place, recording the activities of the same individuals or dealing with the same topics. A better term for them in French is possibly 'fonds d'archives' which has not equivalent in English. ${ }^{4}$ Their owners accumulated them until they were no longer useful or the owners left their homes-after a catastrophe of some kind, for example. In fact, cuneiform archives usually kept on growing-with some interruptions from time to time-until something happened that put an end to the collection-when the building in which they were kept collapsed or was abandoned, for example. ${ }^{5}$ This moment can be determined from the dates of the latest records. Such archives were used for practical purposes.

Archives sometimes contained a few samples of literary texts: an Old Assyrian version of the Legend of Sargon was preserved inside a merchant's archive, for instance (Günbatt1 1998). We occasionally find archival texts in libraries as well, as in the Royal Library of Aššurbanipal (Parpola 1986).

\subsection{Dead and living archives}

Assyriologists usually distinguish between 'dead archives', i.e. tablets that have expired, been cancelled, thrown away or recycled, and 'living archives', which are

3 CT 22, 1: 27-30, edited by Frame/George 2005, 280-281.

4 See the detailed introduction to cuneiform archives by Veenhof 1986.

5 Concerning the end of archives, see the contributions in Joannès 1995. 
tablets normally discovered in situ that belonged to the last person who lived in the building in which they were discovered (Charpin 1985, 255). Both dead and living archives were left on the spot when the buildings housing them were destroyed. Maria Brosius prefers the expressions 'active' or 'working' archive 'to express the fact that an archive was in constant use during its lifetime' (Brosius 2003, 9).

It is worth noting that in the Old Assyrian dialect, some tablets bearing loan contracts could 'die' (muātum) or be 'killed' (duākum), i.e. cancelled, when the debt was repaid because they had no more legal validity (Veenhof 1987, 47-48). There were many ways to 'kill' a tablet: by destroying it physically, putting a specific mark on it or simply by breaking the envelope in which the tablet was kept and which bore the seal impressions of the witnesses and parties involved. In such cases, the 'dead' tablet could be kept as a memorandum together with the 'living archives’, possibly stored in a different container (Michel 1995).

\subsection{Official and private archives}

Assyriologists also make a distinction between official archives from large organisations, temples, palaces, and governmental institutions on the one hand and private archives belonging to individuals on the other, the latter usually being excavated in buildings that were once their homes (Veenhof 1986, 9). Palace archives often contain a large proportion of administrative texts, which document the 'economic resources handled by the palace' (Sallaberger 2013, 220). The tablets found in the Ebla Early Dynastic Palace G (in north-western Syria, twentyfourth century BCE) often consisted of registers of incomes and deliveries, not to mention inventories of stock, but they also contained diplomatic letters and treaties as well, or descriptions of rituals and school texts (Archi 2003). ${ }^{6}$ Palace chancery archives found in Mari (Middle Euphrates, eighteenth century BCE) also included royal correspondence (Durand 1997-2000). Private archives contain details of the economic and social realities of the society that produced them, sometimes on domestic affairs and daily life.

These are naturally modern definitions, and in some cases, there is no clear distinction between official and private archives. As an example, among the archives of Šamaš-hazir discovered at Larsa (eighteenth century BCE), we find letters sent by King Hammurabi of Babylon to his high official and letters sent by

\footnotetext{
6 Texts from Ebla are accessible in the following database: http://virgo.univie.it/eblaonline/ cgi-bin/home.cgi. Photos of the Ebla tablets preserved at Idlib Museum are accessible at this source: http://cdli.ucla.edu/search/search_results.php?Collection=Idlib\&Provenience=Ebla.
} 
Šamaš-hazir to his own wife while he was away from home (Kraus 1968; Veenhof 2005, nos 162-164).

Archaeologists have sometimes found tablets that were issued by officials in private archives. For example, some of the letters that the king of Aššur sent to the Assyrian assembly in Kaneš were kept by merchants at Kaneš (Central Anatolia, nineteenth century BCE), apparently because these letters contained verdicts about a case in which they were involved (Michel 2015d). In another case, some administrative texts concerning the temple in the ancient city of Sippar (seventeenth century BCE) were discovered at Tell ed-Der in the remains of a house belonging to Ur-Utu, the chief lamentation priest of the goddess Annunitum; these tablets were found among a large number of other texts relating to Ur-Utu and his family (2,500 tablets were retrieved altogether).

In contrast, tablets containing private information have also been found in palaces and temples. In the palace of Nuzi (Transtigris, fourteenth century), for example, archaeologists unearthed the archive of Tulpunnaya, daughter of Šeltunnaya, in room $\mathrm{N} 120$. This was found to contain 37 tablets, most of which were contracts (Abrahami/Lion 2012). Tablets were also found in the Nuzi temple which would have been identified as belonging to private archives if the archaeological context had not been so clear (Jas 2000). In first-millennium Assyria, the governor's palace at Kalhu contained private archives belonging to the officials who used to work there (Postgate 1973).

Tablets discovered in private houses often concern several generations of a family, but look more like piles of individual archives than related family archives. They are often the result of sorting, which was done from time to time, a fact that must be taken into account when studying such archives. In the city of Sippar in the eighteenth century BCE, for example, Ur-Utu, the chief lamentation priest of the goddess Annunitum, was sorting his tablets when his house fell down; texts have been discovered in various places in his house, sorted according to their content (Tanret 1991). 


\section{Old Assyrian private archives}

The archives of the Assyrian merchants are the first large group of private cuneiform archives in the history of ancient Mesopotamia; they mainly date back to the nineteenth century BCE. ${ }^{7}$

\subsection{The archaeological and historical context}

Private archives have been unearthed at Kültepe, the ancient town of Kaneš, $21 \mathrm{~km}$ north-east of the modern town of Kayseri in Central Anatolia. Official excavations started in 1948 under the scientific direction of Tahsin Özgüç, who worked there for 57 years until his death in 2005 (Özgüç 2003). In 2006, the excavation teams adopted some new methodologies under the direction of Fikri Kulakoğlu (Kulakoğlu/Kangal 2010). Every year up to 2005, archaeologists found Old Assyrian tablets in the lower town. Since then, the excavations have mainly been carried out on the mound, but during the annual cleaning of the lower town, a few tablets still get unearthed regularly. The total number of tablets discovered at Kaneš, 22,500, makes this site one of the biggest sources of cuneiform tablets from the ancient Near East.

Kültepe is a huge site measuring about 200 hectares with an estimated population of around 30,000 inhabitants (Barjamovic 2014). It is divided into two main sectors: the mound and the lower town. Much of the top of the mound has been destroyed by illicit digging (Özgüç 1999). The remains of a huge palace with about sixty rooms dating back to the eighteenth century BCE have been uncovered. It seems that this building was emptied before being destroyed by a fire, which means that almost no tablets were found in it. Two nineteenth-century palaces have also been partly unearthed, but did not contain any tablets (Michel 2015a). Since 2009, archaeologists have been uncovering a very large official building dating back to the early Bronze Age (end of the third millennium BCE), a period during which there was no writing in Anatolia (Kulakoğlu 2015, Kulakoğlu/Öztürk 2015). All in all, only 40 cuneiform tablets were found in the mound. We do not have any official archives kept by the local rulers-in fact, these may never have even existed.

7 For a catalogue raisonné of the Old Assyrian tablets and a bibliography, see Michel 2003, with supplements in Michel 2006; 2011a and 2015c. There have been several publications dedicated to the Old Assyrian archives, such as Michel 1998, Veenhof 2003a, 2013a; on filing specific archives, see Larsen 2008, Michel 2016; on women's archives, see Michel 2009, and on Anatolian archives, see Michel 2011b. 


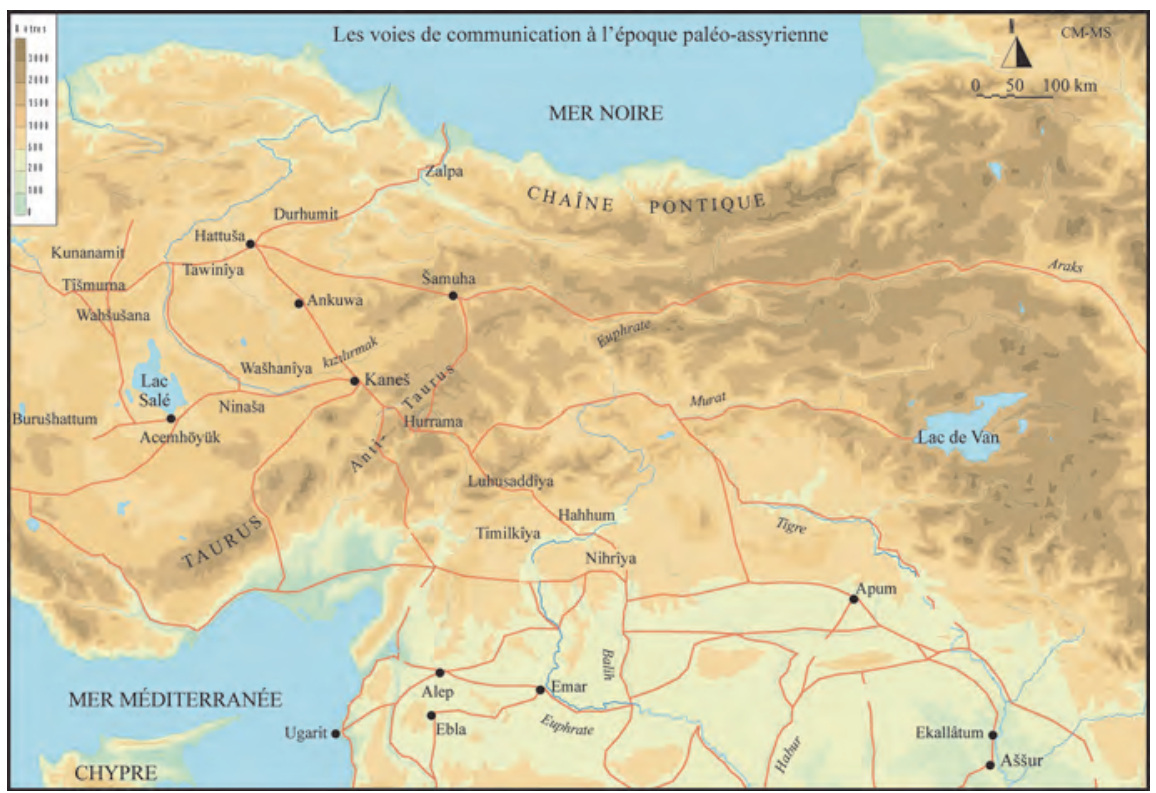

Fig. 1: Roads in Anatolia and Upper Mesopotamia during the Old Assyrian period.

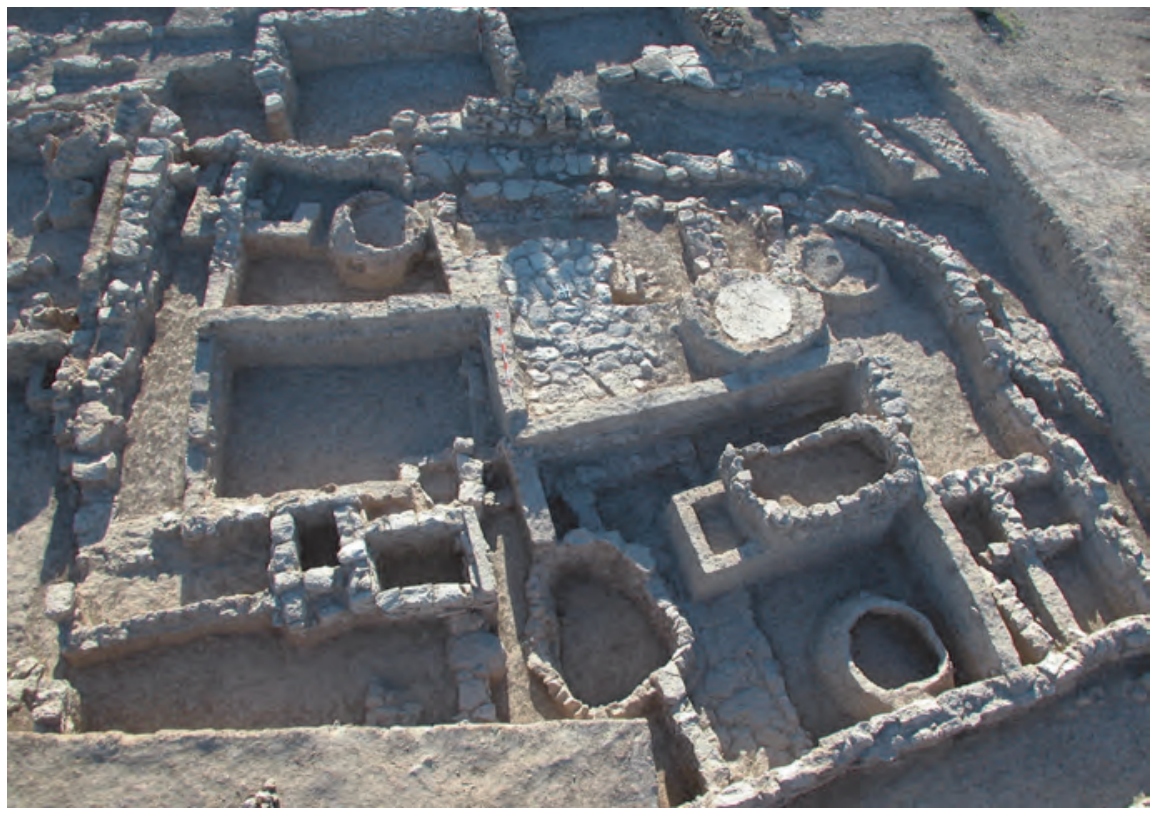

Fig. 2: Houses in the lower town. (C) Kültepe Archaeological Mission. 
In the lower town, only part of the merchant district about nine hectares in size has been excavated up to now, which is located north-east of the mound. Roughly 3,000 to 3,500 inhabitants may have lived there during its main period of habitation (level II of the excavations), the majority of them Assyrians (Hertel 2014); this period largely corresponds to the nineteenth century BCE. This commercial district is divided into quarters separated by large streets and open spaces. A host of artefacts have been excavated in the houses, including some 22,000 clay tablets. At the end of this period, many houses burnt down, which actually baked the tablets, helping to preserve them for posterity. The next level, level Ib (eighteenth century BCE), has only provided 460 tablets up to now, even though the site was more densely inhabited in this period than it was in 'level II'.

The Assyrian merchants who owned houses in Kaneš originally came from Aššur, located on the River Tigris south of Mosul in modern-day Iraq. Aššur has been excavated on and off for a century, but because of various wars the excavations have not been conducted for more than a total of 30 years (Marzahn/Salje 2003). The archaeological discoveries from the beginning of the second millennium BCE are rare and lie scattered about-the main constructions to have been unearthed to date are official or religious buildings-and the Old Assyrian district has not been identified yet, apart from some graves belonging to rich merchants (Hockmann 2010). Thus, for the Old Assyrian period, Aššur has only supplied us with 24 tablets scattered among later archives, including school texts and some 30 royal inscriptions from temples (Grayson 1987). So all we can say about Assyrian society is based on the private archives of the Assyrian merchants who settled in Anatolia, mostly in Kaneš; these archives are currently being deciphered by a dozen specialists from Europe and Turkey.

At the beginning of the second millennium BCE, Aššur was an independent city-state dominated by an oligarchy of merchants. The city played an important role in large-scale trade from the third millennium onwards. Encouraged by political and economic measures taken by Aššur kings and commercial treaties concluded with the local authorities (Günbatt1 2004, Veenhof 2003b; 2013b), the merchants developed long-distance trade links to Central Anatolia, settling down there and building up some forty trade settlements whose centre was located in Kaneš. 


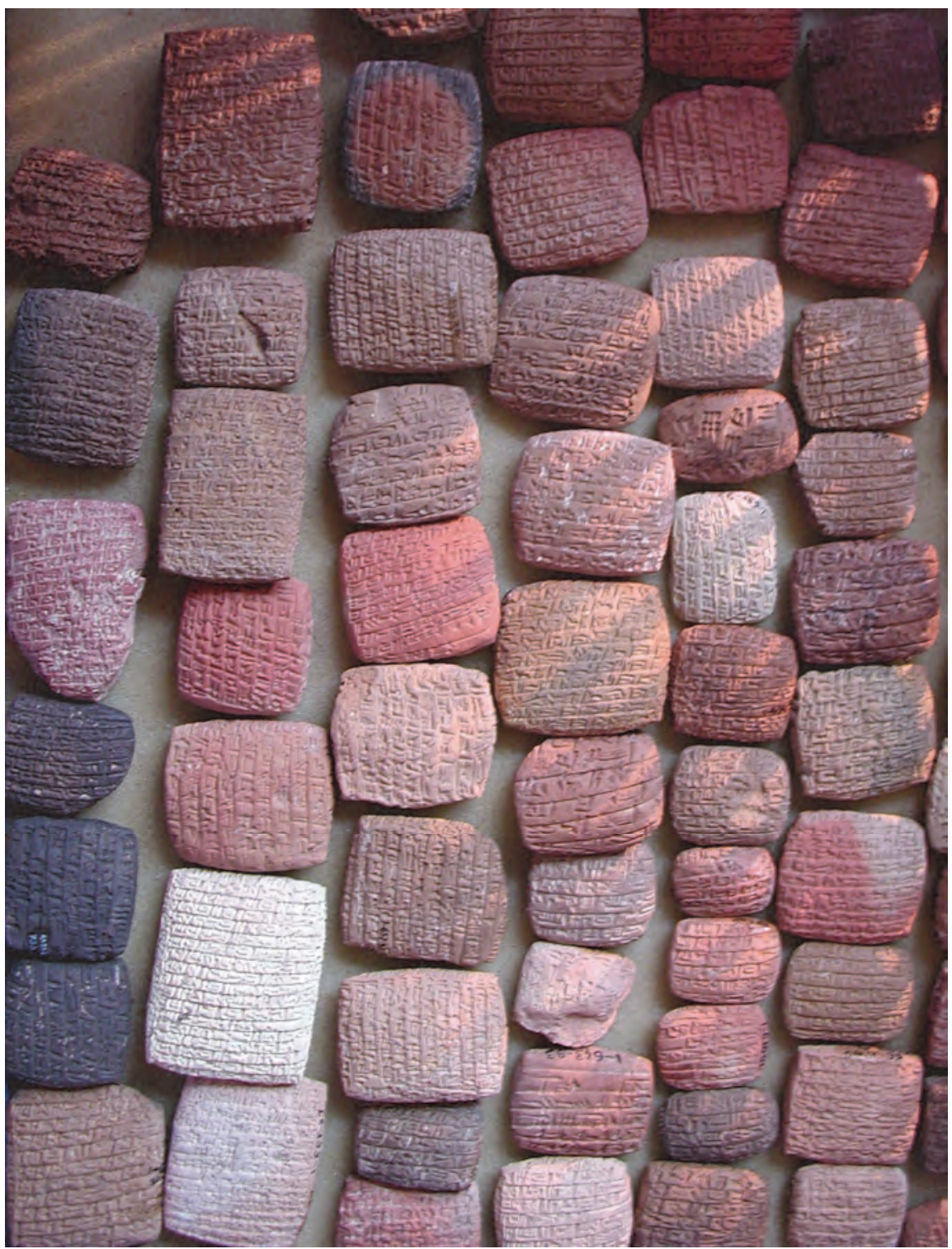

Fig. 3: Tablets belonging to the archives of Ali-ahum and Aššur-taklāku. Photo: Cécile Michel. (c) Kültepe Archaeological Mission. 


\subsection{The contents and purpose of Old Assyrian archives}

The Old Assyrian tablets excavated in the lower town of Kültepe mainly belonged to Assyrian merchants who had originally settled there during the first half of the nineteenth century BCE. In their letters, when they mention their archives, the Assyrians usually referred to them as 'my tablets' (tuppūa), as in the expression 'open my tablets (container)' (țuppēa peteā) or 'my tablets' containers' (șiliānū/ tamalākū ša tuppēa). The word 'tablet' (țuppum, from the Sumerian DUB) is a generic term which corresponds to the object itself on which a text is written, a 'letter' or a 'legal text', and in the plural 'the group of tablets forming (part of) an archive'.

The tablets found in an archive may be classified into several text genres according to modern categories: letters, legal texts, personal memoranda and noncommercial texts.

\subsubsection{Letters}

A letter is referred to by the words țuppum ('tablet') or našpertum ('message', 'shipment'). Letters often make up a large part of an archive-from 40 to $45 \%$ of it. They provide a considerable amount of data about the way trade was organised, but also cover domestic matters and aspects of daily life. They are never dated, however (Michel 2001; 2008a). The displacement of family members and colleagues to Central Anatolia explains the existence of so many Old Assyrian letters; these were a unique means of communication between the inhabitants of Kaneš and their families and colleagues in Aššur, and the only way to exchange news. In one case, a woman wrote to a relative of hers, saying: 'I'm fine. Don't worry! Please send me some news about yourself and the household as soon as you hear my letter' (Michel 2001, no. 373). And in another case, a merchant explained that he had been writing a lot of correspondence: 'I have exhausted the clay of this town by constantly sending you letters.'

There was no standard size for letters: the size simply depended on the length of the message to be written. Some were extremely short, written on very small tablets, as suggested by a woman who wished to receive some news from her relatives: 'Why haven't you even sent me a tablet two fingers long with some good

$8 \mathrm{Kt}$ 89/k 232: 6-8, ți-țá-am, ša a-lim ${ }^{\mathrm{ki}}$ : a-nim i-na, tí-ša-pu-ri-im: ag-da-am-ra-ku-ni-ma (cited by Veenhof 2008, 201, n. 8). See also AKT 4, 30: 28-29 and Kt n/k 161: 37-38. 
news?', she wrote. ${ }^{9}$ Other tablets could be very long, spanning more than a hundred lines. The size originally planned sometimes turned out to be too small, so a second flat, oval tablet written on one side was added to the first tablet. The Assyrians called this second 'page' șibat tuppim, i.e. 'additional tablet' (Veenhof 2003a, 91). It is not easy for researchers to match up the first and second pages if these got separated.

Letters were covered by clay envelopes which reveal the identity of the correspondents as well as the sender's seal impression, which was usually made with a cylinder seal that produced a long, rectangular miniature scene sometimes including the name of its owner. The envelope protected the confidentiality of the letter and the tablet during transportation. Letters enclosed in envelopes were wrapped in textiles and leather to protect them when they were sent off to Kaneš using caravans of donkeys; it took about six weeks to reach the town.

When a merchant received a letter, he first had to break the envelope to read the text. Envelopes should thus have been open in Antiquity. However, many envelopes and fragments of envelopes have been discovered in Old Assyrian archives, which suggests that they did not get opened. Some of them will have got broken when the house they were kept in was destroyed (most of the pieces are generally found by archaeologists). Indeed, some letters were never even sent off. In other cases, their intended recipients were out when they were delivered or had even died by the time they arrived, so the envelopes did not get opened. Preserved envelopes allow the identification of the seal users. These envelopes also kept the two pages of long letters together, which often got separated once an envelope was opened.

The recipient kept the letters he received in his archives for personal reasons or because of the information they contained-as a reminder of his commercial activities, because of the answers received from colleagues or representatives to whom he had given instructions, etc. One could also keep copies of the letters one sent, as we learn from a letter written by a merchant whose archives have been unearthed in Kaneš: 'I have kept a copy of all the tablets I have sent you over time.' ${ }^{\prime 10}$

9 ICK 1, 17: 4-7: mì-nu-um : a-ni-tum, ša țup-pá-am 2 ú-ba-an, šu-lu-um-ku-nu, lá tù-šé-ba-lá-ni-ni. 10 CCT 2, 6: 14-15, mì-ma țup-pì ša uš'-té-né-ba-lá-ku-n[i], me-eh-ri-šu-nu : ú-kà-al. 


\subsubsection{Contracts and other legal texts}

Tablets containing legal texts usually form a second category: contracts and judicial records (Michel 2000a, Hertel 2013, 133-183). Numerous contracts have been discovered; they concern family law (marriage, divorce and wills), loans and receipts for repayments, caravan services and transport, investments, deposits, business partnerships, deeds of purchase and so on. The judicial records contain witnessed depositions, records of private arbitration cases, binding orders, verdicts, etc. The legal validity of such tablets is certified (tuppum harmum) by an envelope sealed by the parties involved and their witnesses (Larsen 1977, Tessier 1994). Seals were often rolled along every single side of the envelope, then the text was written. It always started with the names of the individuals who had sealed the envelope, but the order of the seals on the envelope is not usually respected. Since the seals are generally uninscribed, it is not very easy to identify their owners nowadays, whereas in the past, family members and colleagues will have recognized the seals their relatives and acquaintances used.

The text written on the envelope usually duplicates the one on the tablet, meaning that it was possible to read it without actually opening the envelope. Indeed, when the envelope was opened, the tablet lost its legal validity. In fact, since clay tablets were never baked, it was always possible to moisten the surface of them and erase particular signs or even whole lines on them. In one case we know of, a merchant specifically asked a colleague to search for a tablet in his archives and erase some lines on it:

Concerning the tablet referring to the house of Wašhuba, which you wrote to me about, take Ilabrat-bāni with you and open the tablets (archive) [...]. There is a tablet concerning a loan of 21 minas 10 shekels of silver that the merchant made to Šalim-Aššur, Ikūnum and Sanasiya, and concerning that silver we share responsibility for. Take that tablet out, examine it and moisten it with water where it says 'the silver was taken in the name of Iliš-tikal', (erase it) and show the son of Šalim-Aššur what is important to you (KTS 2, 9; see Michel 1995, 25, n. 47).

Loan contracts are the most numerous in the category of legal texts and concern loans in silver, grain and copper. These are simple loans or, more often, loans issued from the credit sale of merchandise. Documents of this type are often dated and were kept in the creditor's archives until the debt was repaid. In exchange for the payment, he had to give the tablet back to the debtor, who would logically 
'kill it', i.e. destroy it: 'Hand the tablets recording my debts over to me so that I can destroy (them)', says one. ${ }^{11}$

Sometimes the tablet was lost or got broken:

\begin{abstract}
We went through Durhumit and saw the fragments of a tablet on which Ṭāb-ṣilli-Aššur, son of Hinnaya, (is named). He got angry with me about the 10 shekels of silver from Aššur-bāni and didn't get the tablet out. He submitted a claim against you, saying: 'We'll take a tablet (order) from the trade office in Kaneš (i.e. the central Assyrian office there) and they will shape our tablets again. Then the trade office at Durhumit will seal them for us' (TPAK 1, 7; see Michel 1995, 23-24).
\end{abstract}

Loan tablets were not cancelled systematically, it seems-lots of them remained in the archives. Those of them preserved in their envelopes were either never repaid or some of the debts were paid elsewhere and the creditor gave a receipt to the debtor. Those preserved without their envelopes had no more legal validity, as we have said, but the debtor still kept them in the archives for his personal accounts (Michel 1998). Many loans were also copied in long memoranda (tahsistum), which were useful to the traders, helping them to remember all their outstanding claims.

The other contracts dealing with long-distance trade concern the hiring of caravan people, the transport or storage of merchandise, investments in business partnerships or joint-stock companies, and closure of accounts. Purchase agreements relate to houses and slaves. The deed of a house purchase was kept by the buyer and used as a title of ownership; it was transferred during every transaction concerning the same building, as we have learnt from some of the contracts that have been found:

They sold the house of Ištar-lamassī and Aššur-țāb to Šalimma for $21 \frac{1}{2}$ minas of silver. And Aššur-țāb and Ištar-lamassī are satisfied with the silver, the price of their house [...]. Aššurțāb gave to Šalimma the contract recording the sale of this house bearing the seal of the Anatolian, its previous owner (Michel forthcoming, no. 148). ${ }^{12}$

There is also a great variety of judicial texts among the tablets that have been discovered: minutes and proceedings of testimonies and arbitrations, and verdicts passed by the Assyrian authorities of Aššur or Kaneš. All these tablets were kept by the individuals who were primarily concerned.

Family-law texts concerned marriage, divorce, inheritance and adoption; the majority of these relate to marriage contracts. Thanks to the seal impressions found on the envelopes, it is possible to know which archive a particular contract

11 TC 3, 264a:7-9, țup-pé-e ša hu-bu-li-a, dì-na-ma, la-du-uk.

12 This kind of practice is well known during the Old Babylonian period; see Charpin 1986. 
was kept in. If the envelope bears the seals of the groom and witnesses, then the contract was kept in the girl's family archives or together with her own tablets, but if the envelope has an impression of the seals on it that were used by the bride's father and/or mother and by the witnesses, the contract was kept in the husband's archives, in some cases as proof that the bride price had been paid (Kienast 2015, Michel forthcoming, chapter 1).

All the legal tablets were kept by the parties involved. The witnesses sometimes also received a copy of the contract to put in their own archives: 'A copy of this tablet is with Ennam-Aššur', says one such find. ${ }^{13}$ Some lists of loans bear a subscript to indicate that the text is a copy of several loans, e.g.: 'this tablet is a copy of the certified tablets. ${ }^{14}$

\subsubsection{Miscellaneous texts}

The other tablets found in archives are all those which have no legal value, and are not letters: lists, private account notices, memoranda and various miscellaneous texts. These are anonymous, so it is often impossible to link them to their owner. It seems they were used as an aid to memory. There are also a few noncommercial texts among them, such as school texts, incantations, lists of eponyms, and rare historical or literary texts.

\subsubsection{Other inscribed objects}

Besides tablets, archives contained bullæ, or pieces of clay which were used both as labels and to close bags and containers. These bullæ had seal impressions and could bear a text linked to the content of the sealed containers or to their owner. Some of the cylinder seals were inscribed with the name of their owners and patronyms. In exceptional cases, other objects could have a very short text: the name of Amurru-bāni was written on a fragment of a jar excavated in 1992, for instance (Kulakoğlu/Kangal 2010, no. 448).

13 TC 3, 211:57-58, me-[he-e]r țup-pí-im a-nim, ki En-na-A-šur.

14 ICK 1, 187:63-64, [țup]-pu-um a-ni-um me-he-e[r], țup-pè ha-ru-m[u-tim]. 

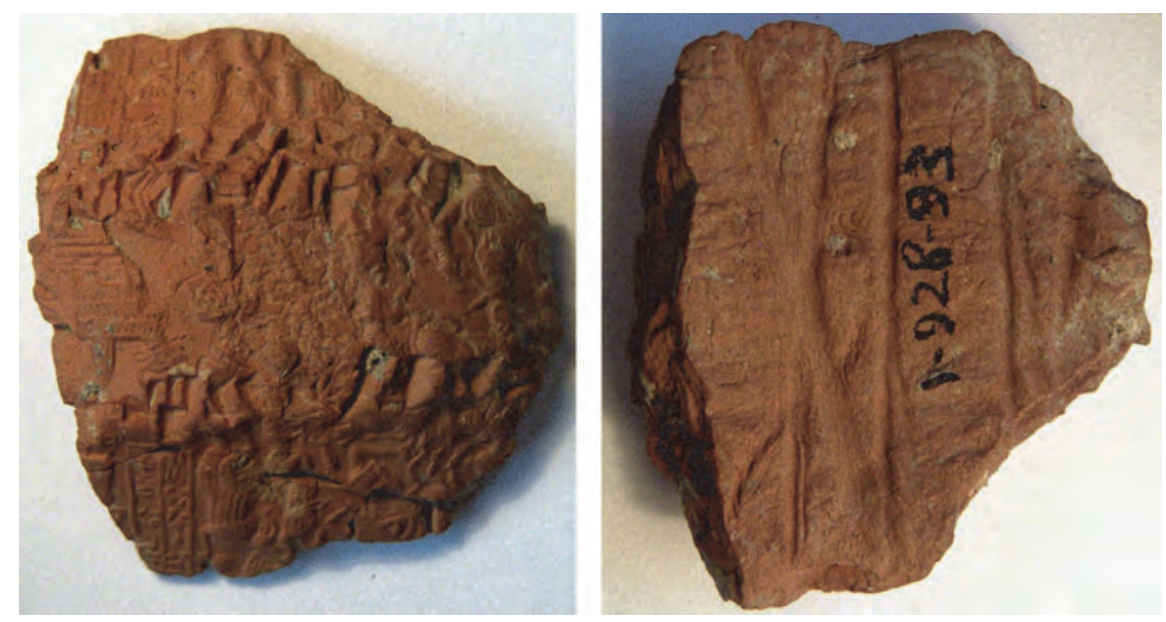

Fig. 4: Bulla Kt 93/k 804. On the recto, the text mentions a shipment to a merchant whose name is broken. There are three seal imprints, two of them bearing the name of their owners, Puzur-Ana, son of Elālī, and Aššur-țāb, son of Ali-ahum. On the verso, there are traces of textiles and strings, suggesting that this bulla was attached to objects (tablets or merchandise) wrapped in a textile. Photos: Cécile Michel. @ Kültepe Archaeological Mission.

\section{The archives and their owners}

Every year since 1948, several houses in Kültepe have been emptied, some of which have contained archives of tablets. Each of these archival groups contains all the tablets accumulated during the lifetime of one or more members of a family. These vary a great deal in terms of their size and content (Michel 2003; 2006; 2011a; 2015c).

To identify the owner of an archive and, by extension, of a house, one has to look for the recipients of letters, providers of loans and persons involved in the other legal texts. The result is not always obvious because some Assyrian merchants did not have a house of their own in Kaneš and left tablets in colleagues' houses instead. A house excavated in 1990 yielded 230 tablets highlighting the activities of two merchants, for example (Michel/Garelli 1997). The first one, Šumi-abiya, son of Puzur-Ištar, was the recipient of several letters and the owner of several loan contracts. His father and brothers also appear as creditors. The second one, Aššur-mūtappil, son of Iddin-abum, was the recipient of several letters, and the only other texts mentioning him also mention Šumi-abiya. So he probably stored his tablets in his colleague's house (Michel 1998). 
This was a common practice, as many texts reveal. In one of these, for example, a trial was taking place that concerned two boxes of tablets that two merchants each claimed to be their own property: 'When I was in Kaneš with my wife, you went to Durhumit, and although I didn't owe you anything, you entered my second home on your own authority and took 2 boxes of tablets with you, which contained ...' [then a detailed description of the tablets follows ] '... and tablets from other people who had left them with me as a safe deposit ...' [then another detailed description of the tablets follows] '... and apart tablets belonging to my witnesses, concerning you and me, which they had certified at the Gate of the God' (CTMMA 1, 84, Michel 2000a, no. 93).

\subsection{The owner of the archive excavated at Kültepe in 1993}

In 1993, archaeologists working on the Kültepe site unearthed a large building or two adjoining houses (named hereafter 'house 1' and 'house 2') in grid LVII/127 and LVIII/127-128 in the lower town, which were badly damaged. These contained almost a thousand tablets, envelopes and fragments. In terms of our modern categories, these tablets may be classified as follows:

\begin{tabular}{ll}
\hline Type of text & \% of total \\
\hline Letters & 40 \\
Loan contracts & 10 \\
Other contracts & 10 \\
Legal proceedings & 7 \\
Personal accounts & 15 \\
Not identified & 18 \\
\hline
\end{tabular}

In terms of proportions, there were more letters in 'house 1' than in 'house 2', while the latter contained more loans and other contracts than the former. Three merchants are often mentioned in this archive, which was spread over several rooms: Aššur-taklāku, Ali-ahum and Iddin-Suen, along with a woman called Tariša (Michel 2008b). ${ }^{15}$ Iddin-Suen was the recipient of 40 letters and the sender of only 4, although these belong to a homonym. The vast majority of the letters sent to Iddin-Suen were discovered in 'house 1'. None of his loan contracts have been found, and only two lawsuits pertain to him.

15 Due to the very poor state of the buildings, there is no exact indication of the tablets' locations. 
Ali-ahum, his son, was the recipient of 31 letters and the author of 18 others, mainly sent to members of his family while he was away. He had a house in Burušhattum and may have had a house in Aššur as well. He was also the owner of 11 loan contracts and was involved in a dozen lawsuits and other judicial matters. The total number of texts related to Ali-ahum in the houses excavated in 1993 is not as substantial, which may be explained by the distribution of his archives in different houses located in Burušhattum and Aššur.

The most frequent correspondent in the 1993 letters is Aššur-taklāku, son of Ali-ahum: he was the author of 72 letters and the recipient of 72 others. He sent a lot of letters to members of his family living in 'house 2'. Since Aššur-taklāku sent as many letters as he received, he presumably travelled a great deal and was away from home for long periods. The numerous loan contracts in which Aššur-taklāku is mentioned as a creditor are the best proof that the archive belonged to him. In fact, he was the creditor behind 48 loan contracts in all, most of which were found in 'house 2'. Finally, about 30 judicial texts exist that reflect his lawsuits and disputes with other merchants.

Some of the women in the family are also mentioned in this archive. Aššrtaklāku's wife, Lušitiya, was the recipient of 7 letters, some of them written by her husband. His sister, Tariša, was the recipient of 26 letters and the sender of 7 . Almost all of the letters she received were written by her brother and were found in 'house 2' where she lived with other members of her family. She had previously spent some time in Ǎšur (Michel 2015b). Other individuals mentioned in this corpus also belonged to the family. Moreover, Elamma, a brother of Ali-ahum whose archives are being studied by Klaas R. Veenhof, practically lived next door (Veenhof 2015); it has thus been possible to reconstruct the whole family tree in this case.

\subsection{The content of the 1993 archive}

This archive concerns three generations of a merchant's family who inhabited two neighbouring houses that were largely destroyed at some point. Obviously, we do not have the entire archive of this family over three generations (see Michel $2008 \mathrm{~b}$ as well). What kind of texts were preserved and what kind of texts are absent?

Let us start with the grandfather, Iddin-Suen. The archive in question contains some letters he received and a few legal texts mentioning action taken in the court of law. More than a third of the letters addressed to Iddin-Suen are only known to us from fragments of their envelopes, which have been preserved together. These letters possibly arrived at Kaneš when their recipient was away or 
already dead; they were kept together in the same container, presumably by Iddin-Suen's son. The absence of any loan contracts relating to Iddin-Suen means that either they were all repaid and the tablets were then discarded or that new tablets concerning the unpaid debts were written in his sons'name.

Ali-ahum, who lived there after his father, at least for a while, left even fewer letters. He owned another house in Burušhattum (south-west of the Tuz Gölü Lake) where he left some tablets as well. It is even possible that he died there. Thus we have only part of his archive in Kaneš.

Aššur-taklāku was the main owner of the archives discovered at Kültepe in 1993 as most of the letters, loan contracts and other legal texts belonged to him. At the time the houses were destroyed, he was the one who had spent the most time there and was one of the last people to be in them. His archive could be called a 'living archive' as his certified loan contracts were still valid.

\subsection{Dating the 1993 archive}

Practically the only tablets to have a date on them are the loan contracts. Most of those excavated in 1993 belong to a period covering 34 years (c. 1893-1859 BCE) and concern Ali-ahum and his son Aššur-taklāku almost exclusively. Only four dates fall outside this period: the oldest one (c.1901 BCE) is on a tablet associated with an anonymous creditor, while the three others bear much later dates lying between c. 1840 and 1838. If we take these extreme dates into account, the dated texts from 1993 span a period of 64 years altogether.

Almost all the loans dated between c. 1893 and 1878 BCE, a 15-year period, concern Ali-ahum, while all the loans in which his son, Aššur-taklāku, appears as the creditor are dated between c. 1877 and 1859 BCE, an 18-year period. This very clear distribution of the loans between the father and the son is only disturbed by a single loan belonging to Ali-ahum dated to the end of $c .1874$ BCE. This suggests that father and son where not active at the same time in Kaneš.

\section{Uses and filing of archives}

The archives were regularly consulted, which explains why so many letters and various texts were kept: the merchants kept every tablet concerning their activities as well as letters from their relatives. Since the archives grew in size over the years, it was obviously necessary to file them. 


\subsection{Use of the archives}

As noted some years ago by Klaas R. Veenhof (2008b, 200):

There probably is no Mesopotamian text corpus in which written documents are mentioned so often and that offers so much information on their writing, consultation, storage, transfer, exchange and cancellation. This explains why many archives contain hundreds of letters, lists and notes and why we frequently read about the making and use of copies of documents (mehrum).

Many tablets were regularly extracted from the archive, consulted and sometimes transferred. As custodians of the tablets, wives could be directed to provide the men in the family with certain ones that they needed. In the following case, a merchant asks his wife and a colleague to retrieve a specific tablet from his archives (AKT 3, 84; Michel forthcoming, no. 214):

I have sealed a tablet with the (names of) my witnesses at the Gate of the God: Aššur-țāb, son of Kīki, and Enna-Suen, son of Ilānum. So look where the tablets have been deposited inside a container at the Gate of the God, take out the tablet with the seal of Aššur-țāb and Enna-Suen, wrap it securely in leather and seal it, then entrust it to Hašta'ili or to Šamašrē'î so he can bring (it) over to me; make sure (to do it properly)!

\subsection{Filing archives}

Every year until 2005, archaeologists unearthed up to three houses in the lower town in Kültepe, some of which contained one or more archives. The houses unearthed in the first half of the 1990s in squares LV-LXV/126-131 mainly belonged to Assyrian merchants. All in all, 4,190 tablets were excavated in eleven or twelve different houses over a five-year period, as the following table shows (the number of houses is indicated in brackets):

- 1990 (1): 242 tablets in the house of Šūmī-abiya, son of Puzur-Ištar, with tablets belonging to Aššur-mūtappil, son of Iddin-abum (published by Michel/Garelli 1997)

- 1990 (2): 123 tablets belonging to PN? (studied by S. Çeçen)

- 1991 (1): 282 tablets + 90 tablets from 1992 in the house of Elamma, son of Iddin-Suen (published by Veenhof, in press)

- 1991 (2): 154 tablets belonging to various other archives

- 1992 (1): 73 tablets + 3 tablets from 1989 in the house of Kuliya (published by Veenhof 2010)

- 1992 (2): 774 tablets in the house of Šū-Ištar, son of Aššur-bāni (Erol 2015) 
- 1993 (1 or 2): 915 tablets + 61 tablets from $1994+2$ tablets from 1998 in the house(s) of Ali-ahum, son of Iddin-Suen and his son Aššur-taklāku (Michel 2008d)

- 1994 (1): 370 tablets presumably in the house of Irma-Aššur (studied by G. Barjamovic)

- 1994 (2): 1,101 tablets in the house of Šalim-Aššur, son of Issu-arik, and his sons (published in Larsen 2010; 2013; 2014).

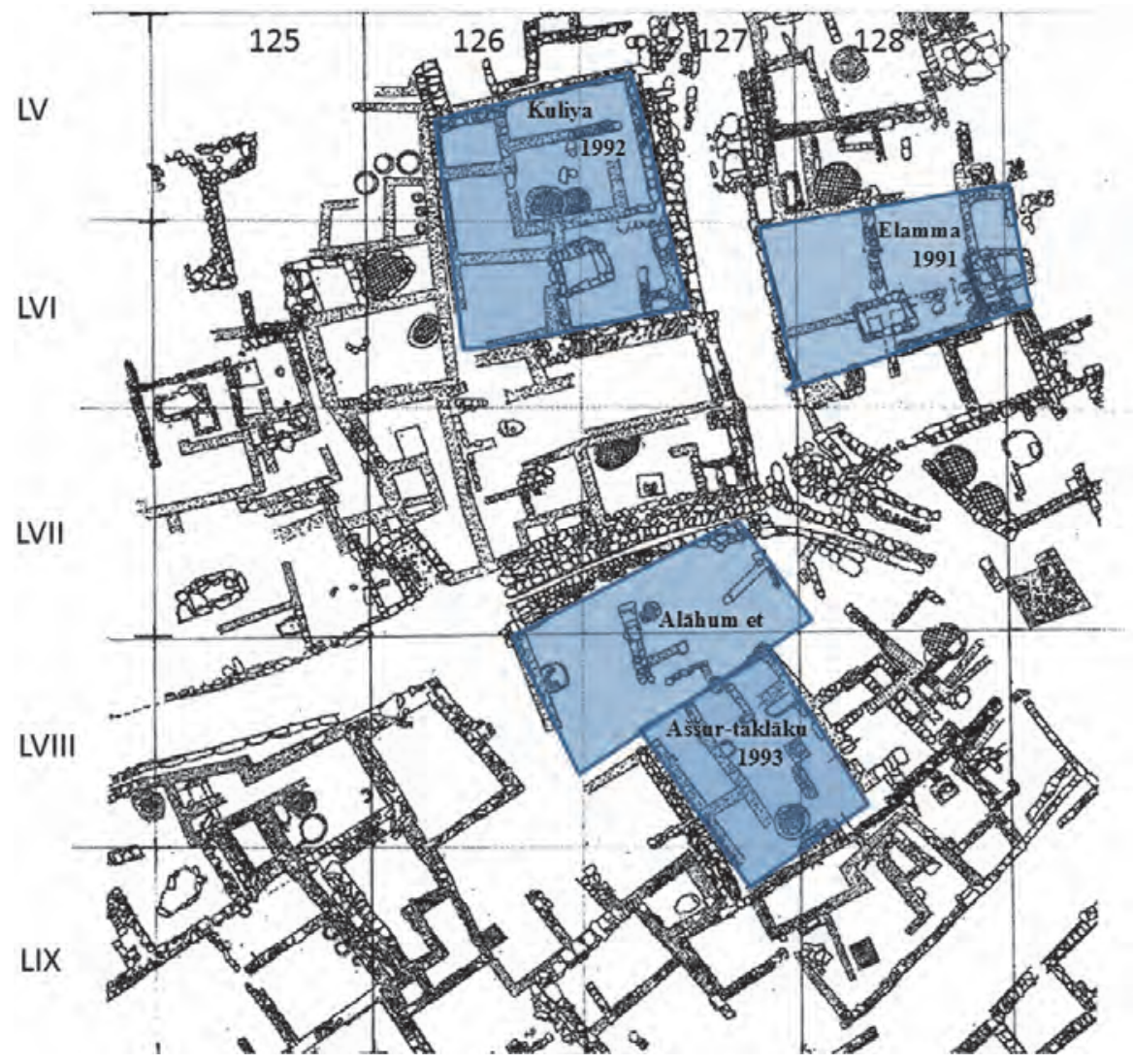

Fig. 5: Plan of a district of the lower town excavated at the beginning of the 1990s. (c) Kültepe Archaeological Mission.

Large archives such as those excavated in 1993 and 1994 contained a thousand or more tablets, which will certainly have required filing. According to excavation reports, tablets were found in piles on the ground in the corners of rooms or along 
the walls of the buildings. They were stored in bags, baskets and chests made of perishable materials or in clay containers. Thus, Elamma's archives excavated in 1991 were 'found along the base of the east wall of room 3 and in rooms 4-5, in groups once packed in boxes, bags, sacks and straw mats. On top of each group lay one or two bullæ' (Özgüç 1994, 369). ${ }^{16}$ Indeed, tablet containers were usually identified by a clay docket or bulla. Unfortunately, the links between the bullæ and the tablets have been lost.

Within a period of sixty years, archaeologists only unearthed 240 bullæ in the commercial district, 144 of which bear a text (bullæ were used to seal all kinds of containers). The texts refer either to merchandise or to tablets. ${ }^{17}$ Some of these bullæ only have a seal on them indicating who the owner of the archive was or what goods had been sealed, but others also bear a short text, which sometimes gives us an idea about the way tablets were filed. In 1963, for example, 207 tablets and 10 bullæ were found in one house (in square B-D/11-12); one of the bullæ bearing the text 'Tablets concerning Agūa's will' (Kt o/k 203) could be linked to the will itself (Kt o/k 196), which was kept in its envelope. Presumably, other tablets linked to Agūa's inheritance were kept in the same container (Michel 2000b).

In the two houses excavated in 1993, the archaeologists unearthed 37 bullæ. The imprints left on the inside of these show traces of strings and ropes and sometimes the type of material on which they were applied: wood, textile, clay, etc. Twenty of these bullæ do not bear any text at all. Two of those applied on tablets' containers are the following (Michel 2016):

- Kt 93/k 273, bearing the seal of Ali-ahum, has a text which indicates that it was used to seal a container with certified tablets, verdicts from the trade office concerning Suen-pilah. According to the traces on the inside of the bulla, the container was protected by a textile attached to it with reeds.

- Kt 93/k 813 was fixed to a reed basket with tablets sealed by the trade office and containing verdicts of the Aššur assembly according to its text.

16 Note, however, that some tablets excavated in 1950 have a pair of holes in one of the vertical edges; according to Dercksen 2015, 50, these were stored by suspending them from a rope. Unbaked clay is quite fragile, however, so this is unlikely; these holes may have been useful during the process of manufacturing the tablets or better for filing. Moreover, holes of this kind are unusual.

17 Bullæ were also attached to merchandise or tablets sent from Aššur to Anatolia or between two different towns in Anatolia; only some of the bullæ found in the houses had archival functions and were used to file archives, for example; see Özgüç/Tunca 2001, 132-133, 307; Veenhof 2003a, 102. 
In fact, most of the bullæ texts deal with certified tablets which are verdicts from the Assyrian trade office in Kaneš or the Aššur assembly, or loan contracts concerning identified merchants. Thus, legal texts were kept separately, classified by topics.

Letters could be arranged according to who their sender was. Some bullæ only bear the name of a merchant (Kt 93/k 807; tablets belonging to Aššurdamiq), referring presumably to tablets belonging to him or letters sent by him. ${ }^{18}$ From the study of the archives excavated in 1993, we also observe that the archives of the successive owners of the houses were arranged in different containers. The letters received by the grandfather, Iddin-Suen, and kept after his death were found in 'house 1', presumably separated from the other tablets.

The tablets belonging to the older generations were also sorted: the vast majority of 1993 archives belonged to Aššur-taklāku, whereas only a few letters and other tablets belonged to his grandfather, Iddin-Suen.

\section{Conclusions}

In summary, the archives found in the houses of Assyrian merchants in the lower town of Kaneš belonged to members of families over several generations. Archives of this kind look more like piles of individual archives than family archives, however. Most of them are the result of sorting, which was necessary from time to time. The archives of the ancestors were kept apart from one another. What's more, the merchants travelled a great deal, and several of them stayed in Anatolia for a while because of their commercial activities before retiring in Aššur; Aššur-taklāku, the main owner of the 1993 archive, stayed in Kaneš for almost twenty years. His father, Ali-ahum, lived in three different towns, Kaneš, Burušhattum and Aššur, and presumably left tablets in each of his three houses there. Consequently, whenever a find is made, it is usually an incomplete archive or an accumulation of 'dossiers'.

Letters were the unique means of communication between the inhabitants of Kaneš and their families and colleagues in Aššur, which explains why there are so many of them in the archives, where they are the oldest texts preserved; they were kept as a reminder of specific acts. This does not necessarily mean that they took precedence over the other types of texts, though; on the contrary, they had

18 Larsen 2008 also suggests that the bulla that bears the words 'For Ali-ahum, son of ŠalimAššur; sealed by Zukua, son of Aššur-idỉ' (Kt 94/k 1059) could be linked to the 14 letters from Zukua to Ali-ahum found in the archive. This author also noted that the 1994 archive contained very old texts, written a century before the destruction of the house in which they were kept. 
less value and were left behind as part of a 'dead' archive, while other texts could be cancelled because they had expired, or they were carefully arranged in dossiers and moved elsewhere when their owner moved house, for example.

Private archives were arranged in logical groups: texts dealing with a specific matter or referring to a certain person, whatever their literary genre, were stored together in a container identified thanks to its bulla. A distinction was usually made between certified tablets preserved in their sealed envelope and tablets with no legal validity. However, the modern classification of cuneiform tablets in terms of text genres (letters, legal texts, memoranda, literary, official inscriptions, etc.) should not hide the ancient logic of archive storage in antiquity.

\section{Abbreviations}

AKT 3 E. Bilgiç, C. Günbattı, Ankaraner Kültepe-Texte, III (Freiburger Altorientalische Studien Beihefte 3), Stuttgart 1995.

AKT 4 i. Albayrak, (Ankara) Kültepe Tabletleri (Kto/k), IV (Türk Tarih Kurumu Yayınları $\mathrm{VI} / 33 \mathrm{~b})$, Ankara 2006.

CCT 2 S. Smith, Cuneiform Texts from Cappadocian Tablets in the British Museum, II, London 1924.

CT 22 R. Campbell Thompson / L. W. King, Cuneiform Texts from Babylonian Tablets, \&c., in the British Museum, XXII, London 1906.

CTMMA 1 M. T. Larsen, in I. Spar (ed.), Tablets, Cones and Bricks of the Third and Second Millennia B.C., Cuneiform Texts in the Metropolitan Museum of Art New York, I, New York 1988.

ICK 1 B. Hrozný, Inscriptions cunéiformes du Kultépé, I (Monografie Archivu Orientálního 14), Prague 1952.

Kt ?/k Tablet found during the Turkish excavations at Kültepe since 1948 and onwards, preserved in the Anadolu Medeniyetleri Müzesi (Museum of Anatolian Civilisations, Ankara).

$\mathrm{Kt} \mathrm{n} / \mathrm{k} \quad$ Tablets found during the 1962 excavations.

Kt o/k Tablets found during the 1963 excavations.

Kt 89/k Tablets found during the 1989 excavations.

Kt 93/k Tablets found during the 1993 excavations.

Kt 94/k Tablets found during the 1994 excavations.

KTS 2 Veysel Donbaz, Keilschrifttexte in den Antiken-Museen zu Stambul, II (Freiburger Altorientalische Studien Beihefte 2), Stuttgart 1989.

TC 3 J. Lewy, Tablettes cappadociennes du Louvre (Textes cunéiformes du Louvre XIX, XX, XXI), Paris 1935-1937.

TPAK 1 C. Michel, P. Garelli, Tablettes paléo-assyriennes de Kültepe, I (Kt 90/k), Istanbul 1997. 


\section{References}

Abrahami, Philippe, and Brigitte Lion (2012), L'archive de Tulpun-naya (Studies on the Civilization and Culture of Nuzi and the Hurrians 19), Cornell, 3-86.

Archi, Alfonso (2003), 'Archival Record-Keeping at Ebla 2400-2340 BC', in Maria Brosius (ed.) 2003, 17-36.

Barjamovic, Gojko (2014), 'The Size of Kanesh and the Demography of Early Middle Bronze Age Anatolia', in Levent Atici, Fikri Kulakoğlu, Gojko Barjamovic and Andrew Fairbairn (eds), Current Research at Kültepe/Kanesh: An Interdisciplinary and Integrative Approach to Trade Networks, Internationalism, and Identity (Journal of Cuneiform Studies Sup. 4), Atlanta, GA, USA: Lockwood Press, 55-68.

Brosius, Maria (ed.) (2003), Archives and Archival Tradition. Concepts of Record-Keeping in the Ancient World (Oxford Studies in Ancient Documents), Oxford: Oxford University Press.

Charpin, Dominique (1985), Les archives d'époque assyrienne (Mari Annales de Recherches Interdisciplinaires 4), Paris.

Charpin, Dominique (1986), 'Transmission des titres de propriété et constitution des archives privées en Babylonie ancienne', in Klaas R. Veenhof (ed.), Cuneiform Archives and Libraries, Papers read at the 30e Rencontre Assyriologique Internationale Leiden, 4-8 July 1983 (Publications de l'Institut historique-archéologique néerlandais de Stamboul 57), Leiden: Nederlands Instituut voor het Nabije Oosten, 121-140.

Clancier, Philippe (2009), Les bibliothèques en Babylonie dans la deuxième moitié du ler millénaire av. J.-C. (Alter Orient und Altes Testament 363), Münster: Ugarit-Verlag.

Dercksen, Jan G. (2015), 'The Archives of Ali-ahum (I). The documents excavated in N-P-O/20 in 1950 ', in Fikri Kulakoğlu and Cécile Michel (eds), Proceedings of the $1^{\text {st }}$ Kültepe International Meeting. Kültepe, 19-23 September, 2013. Studies dedicated to Kutlu Emre (Kültepe International Meeting 1, Subartu XXXV), Turnhout: Brepols, 47-58.

Erol, Hakan (2015), 'The Archives of Šu-Ištar son of Aššur-bāni (Kt 92/k 264-1008)', in Fikri Kulakoğlu and Cécile Michel (eds), Proceedings of the $1^{\text {st }}$ Kültepe International Meeting. Kültepe, 19-23 September, 2013. Studies dedicated to Kutlu Emre (Kültepe International Meeting 1, Subartu XXXV), Turnhout: Brepols, 59-73.

Faraguna, Michele (ed.) (2013), Archives and archival documents in ancient societies: Legal documents in ancient societies IV, Trieste 30 September-1 October 2011, Trieste (http://www.openstarts.units.it/dspace/handle/10077/8649)

Frame, Grant, and Andrew R. George (2005), 'The Royal Libraries of Nineveh: New Evidence for King Ashurbanipal's Tablet Collecting', in Iraq, 67, 265-284.

Grayson, Kirk A. (1987), Assyrian Rulers of the Third and Second Millennium BC (to 1115 BC) (The Royal Inscriptions of Mesopotamia, Assyrian Periods, 1), Toronto: University of Toronto Press.

Günbattı, Cahit (1998), ‘Kültepe'den Akadlı Sargon'a Ait Bir Tablet', in Archivum Anatolicum, 3, 131-155.

Günbattı, Cahit (2004), 'Two treaty texts found at Kültepe', in Jan Gerrit Dercksen (ed.), Assyria and Beyond. Studies Presented to Mogens Trolle Larsen (Publications de l'Institut historique-archéologique néerlandais de Stamboul 100), Leiden: Nederlands Instituut voor het Nabije Oosten, 249-268. 
Hertel, Thomas Klitgaard (2013), Old Assyrian Legal Practices. Law and Dispute in the Ancient Near East (Old Assyrian Archives Studies 6, Publications de l'Institut historique-archéologique néerlandais de Stamboul 123), Leiden: Nederlands Instituut voor het Nabije Oosten.

Hertel, Thomas Klitgaard (2014), ‘The Lower Town of Kültepe: Urban Layout and Population', in Levent Atici, Fikri Kulakoğlu, Gojko Barjamovic and Andrew Fairbairn (eds), Current Research at Kültepe/Kanesh: An Interdisciplinary and Integrative Approach to Trade Networks, Internationalism, and Identity (Journal of Cuneiform Studies Sup. 4), Atlanta, GA, USA: Lockwood Press, 25-54.

Hockmann, Daniel (2010), Gräber und Grüfte in Assur, I: Von der zweiten Hälfte des 3. bis zur Mitte des 2. Jahrtausends v. Chr. (Wissenschaftliche Veröffentlichungen der Deutschen Orient-Gesellschaft 129), Wiesbaden: Harrassowitz.

Jacquet, Antoine (2013), 'Family Archives in Mesopotamia during the Old Babylonian Period', in Michele Faraguna (ed.) 2013, 63-85.

Jas, Remko M. (2000), 'Old and New archives from Nuzi', in A.C.V.M. Bongenaar (ed.), Interdependency of Institutions and Private Entrepreneurs (MOS Studies 2), Istanbul, 213-228.

Joannès, Francis (ed.) (1995), 'Les phénomènes de fin d'archives en Mésopotamie : Présentation', in Revue d'Assyriologie et d'Archéologie Orientale, 89, Paris.

Kienast, Burkart (2015), Das altassyrische Eherecht. Eine Urkundenlehre (SANTAG 10), Wiesbaden: Harrossowitz.

Kraus, Fritz Rudolf (1968), Briefe aus dem Archive des Šamaš-Hazir: in Paris und Oxford (TCL 7 und OECT 3) (Altbabylonische Briefe 4), Leiden: Brill.

Kulakoğlu, Fikri (2015), 'Current Research at Kültepe', in Fikri Kulakoğlu and Cécile Michel (eds), Proceedings of the 1st Kültepe International Meeting. Kültepe, 19-23 September, 2013. Studies Dedicated to Kutlu Emre (Kültepe International Meetings 1, Subartu XXXV), Turnhout: Brepols, 9-21.

Kulakoğlu, Fikri, and Selmin Kangal (2010), Anadolu'nun Önsözü Kültepe Kaniş-Karumu. Asurlular Istanbul'da/Anatolia's Prologue Kültepe Kanesh Karum. Assyrians in Istanbul (Kayseri Metropolitan Municipality Cultural Publication 78), Istanbul.

Kulakoğlu, Fikri, and Güzel Öztürk (2015), 'New Evidence for International Trade in Bronze Age Central Anatolia: Recently Discovered Bullae at Kültepe-Kanesh', in Antiquity 89/34 (http://journal.antiquity.ac.uk/projgall/kulakoglu343).

Larsen, Mogens Trolle (1977), 'Seal Use in the Old Assyrian Period', in McGuire Gibson and Robert D. Biggs (eds), Seals and Sealing in the Ancient Near East (Bibliotheca Mesopotamica 6), Malibu: Undena Publications, 89-105.

Larsen, Mogens Trolle (2008), 'Archives and filing systems at Kültepe', in Cécile Michel (ed.), Old Assyrian Studies in Memory of Paul Garelli (Old Assyrian Archives Studies 4, Publications de l'Institut historique-archéologique néerlandais de Stamboul 112), Leiden: Nederlands Instituut voor het Nabije Oosten, 77-88.

Larsen, Mogens Trolle (2010), (Ankara) Kültepe Tabletleri VI-a. The Archive of Šalim-Aššur, Family volume 1: The First Two Generations (Türk Tarih Kurumu Yayınları VI/33c), Ankara: Türk Tarih Kurumu.

Larsen, Mogens Trolle (2013), (Ankara) Kültepe Tabletleri VI-b. The Archive of Šalim-Aššur, Family volume 2: Ennam-Aššur (Türk Tarih Kurumu Yayınları VI/33d-b), Ankara: Türk Tarih Kurumu. 
Larsen, Mogens Trolle (2014), (Ankara) Kültepe Tabletleri VI-c. The Archive of Šalim-Aššur, Family volume 3: Ali-ahum (Türk Tarih Kurumu Yayınları VI/33d-c), Ankara: Türk Tarih Kurumu.

Marzahn, Joachim, and Beate Salje (eds) (2003), Wiedererstehendes Assur: 100 Jahre deutsche Ausgrabungen in Assyrien, Mainz: Philipp von Zabern.

Michel, Cécile (1995), 'Validité et durée de vie des contrats et reconnaissances de dette paléoassyriens', in Francis Joannès (ed.) 1995, 15-27 (http://halshs.archives-ouvertes.fr/halshs-00821255).

Michel, Cécile (1998), 'Quelques réflexions sur les archives récentes de Kültepe', in Sedat Alp and Aygül Süel (eds), 3. Uluslararası Hititoloji Kongresi Bildirileri, Ankara, 419-433 (http://halshs.archives-ouvertes.fr/halshs-00708857).

Michel, Cécile (2000a), 'Les litiges commerciaux paléo-assyriens', in Francis Joannès (ed.), Rendre la justice en Mésopotamie. Archives judiciaires du Proche-Orient ancien (IIle-ler millénaire avant J.-C.), Saint-Denis, 113-139 (http://halshs.archives-ouvertes.fr/halshs00821273).

Michel, Cécile (2000b), ‘À propos d'un testament paléo-assyrien: une femme 'père et mère' des capitaux', in Revue d'Assyriologie et d'Archéologie orientale, 94, 1-10 (http://halshs.archives-ouvertes.fr/halshs-00642823).

Michel, Cécile (2001), Correspondance des marchands de Kaniš au début du Ile millénaire av. J.-C. (Littératures du Proche-Orient ancien 19), Paris : Cerf.

Michel, Cécile (2003), Old Assyrian Bibliography of Cuneiform Texts, Bullæ, Seals and the Results of the Excavations at Assur, Kültepe/Kanis, Acemhöyük, Alishar and Bogazköy (Old Assyrian Archives Studies 1, Publications de l'Institut historique-archéologique néerlandais de Stamboul 97), Leiden.

Michel, Cécile (2006), 'Old Assyrian Bibliography 1 (February 2003-July 2006)', in Archiv für Orientforschung, 51, 436-449.

Michel, Cécile (2008a), 'La correspondance des marchands assyriens du XIXe s. av. J.-C.: de l'archivage des lettres commerciales et privées', in Laure Pantalacci (ed.), La lettre d'archive. Communication administrative et personnelle dans l'Antiquité proche-orientale et égyptienne (Topoi Suppl. 9), Le Caire, 117-140 (http://halshs.archives-ouvertes.fr/halshs00644198).

Michel, Cécile (2008b), 'The Alāhum and Aššur-taklāku archives found in 1993 at Kültepe Kaniš', in Altorientalische Forschungen, 35, 53-67 (abstract p. 359) (http://halshs.archivesouvertes.fr/halshs-01186428).

Michel, Cécile (2009), 'Les femmes et l'écrit dans les archives paléo-assyriennes (XIXe s. av. J.C.)', in Françoise Briquel-Chatonnet, Saba Fares, Brigitte Lion and Cécile Michel (eds), Femmes, cultures et sociétés dans les civilisations méditerranéennes et proches-orientales de l'Antiquité (Topoi Supplément 10), Lyon, 253-272 (http:// halshs.archives-ouvertes.fr/halshs-00644211).

Michel, Cécile (2011a), 'Old Assyrian Bibliography 2 (August 2006-April 2009)', in Archiv für Orientforschung, 52, 416-437.

Michel, Cécile (2011b), 'The Private Archives from Kaneš Belonging to Anatolians', in Maria Elena Balza (ed.), Archival, Scribal, and Administrative Spaces among the Hittites, Altorientalische Forschungen, 38, 94-115 (http://halshs.archives-ouvertes.fr/halshs-01186438).

Michel, Cécile (2015a), 'L'organisation du palais de Kaneš d'après la documentation textuelle', in Cécile Michel (ed.), Bâtiments publics et lieux de pouvoir dans l'Orient ancien, Thème 
VIII (Cahiers des thèmes transversaux d'ArScAn 12, 2013-2014), Nanterre, 161-174

(https://halshs.archives-ouvertes.fr/halshs-01186393).

Michel, Cécile (2015b), 'Women in the Family of Ali-ahum son of Iddin-Suen (1993 Kültepe archive)', in Fikri Kulakoğlu and Cécile Michel (eds), Proceedings of the 1st Kültepe International Meeting, Kültepe, 19-23 September, 2013. Studies Dedicated to Kutlu Emre (Kültepe International Meetings 1, Subartu XXXV), Turnhout: Brepols, 85-93.

Michel, Cécile (2015c), 'Old Assyrian Bibliography 3 (May 2009-June 2015)', in Archiv für Orientforschung, 53, 525-559.

Michel, Cécile (2015d), 'Les lettres des rois d’Aššur découvertes à Kaniš (XIXe siècle av. J.-C.)', in Stefan Procházka, Lucian Reinfandt and Sven Tost (eds), Official Epistolography and the Language(s) of Power. Proceedings of the First International Conference of the Research Network Imperium \& Officium. Comparative Studies in Ancient Bureaucracy and Officialdom. University of Vienna, 10-12 November 2010 (Papyrologica Vindobonensia 8), Vienna: Verlag der österreichischen Akademie der Wissenschaften, 43-60 (https://halshs.archives-ouvertes.fr/halshs-01426483).

Michel, Cécile (2016), 'Quelques remarques sur les bullæ inscrites de la ville basse de Kültepe', in Bérengère Perello and Aline Tenu (eds), Parcours d'Orient. Recueil de textes offerts à Christine Kepinski, Oxford: Archaeopress, 175-184.

Michel, Cécile (forthcoming), Women from Aššur and Kaniš according to the private archives of the Assyrian merchants at beginning of the II $^{\text {nd }}$ millennium B.C. (Writings from the Ancient World, SBL), Baltimore.

Michel, Cécile, and Paul Garelli (1997), Tablettes paléo-assyriennes de Kültepe, I: (Kt 90/k), Istanbul: Institut Francais d'Etudes Anatoliennes / De Boccard.

Özgüç, Nimet, and Önhan Tunca (2001), Kültepe-Kanis. Sealed and Inscribed Clay Bullæ (Türk Tarih Kurumu Yayınları V. Dizi - Sayi 48), Ankara: Türk Tarih Kurumu Basimevi.

Özgüç, Tahsin (1994), 'A Boat-Shaped Cult-Vessel from the Karum of Kanish', in Hermann Gasche et al. (eds), Cinquante-deux réflexions sur le Proche-Orient Ancien offertes en hommage à Léon de Meyer (Mesopotamian History and Environment, Occ. Publ. II), Leuven: Peeters, 369-375.

Özgüç, Tahsin (1999), The Palaces and Temples of Kültepe-Kaniš/Neša (Türk Tarih Kurumu Yayınları V/46), Ankara: Türk Tarih Kurumu Basımevi.

Özgüç, Tahsin (2003), Kültepe Kaniš/Neša. The earliest international trade center and the oldest capital city of the Hittites (The Middle Eastern Culture Center in Japan), Istanbul: Yap। Kredi Yayınları.

Parpola, Simo (1986), ‘The Royal Archives of Niniveh', in Klaas R. Veenhof (ed.) 1986, 223-236.

Pedersén, Olof (1986), Archives and Libraries in the City of Assur. A Survey of the Material from the German Excavations, part I: 1985, part II: 1986 (Acta Universitatis Upsaliensis 6), Uppsala: Uppsala University.

Pedersén, Olof (1998), Archives and Libraries in the Ancient Near East 1500-300 BC, Bethesda: CDL Press.

Posner, Ernst M. (1972), Archives in the Ancient World, Cambridge: Harvard University Press.

Postgate, John Nicholas (1973), The Governor's Palace Archive (Cuneiform Texts from Nimrud 2, British School of Archaeology in Iraq), Hertford: Stephen Austin and Sons, Ltd.

Sallaberger, Walther (2013), 'The Management of Royal Treasure. Palace Archives and Palatial Economy in the Ancient Near East', in Jane A. Hill, Philip Jones and Antonio J. Morales (eds), Experiencing Power, Generating Authority. Cosmos, Politics, and the Ideology of 
Kingship in Ancient Egypt and Mesopotamia, Philadelphia: University of Pennsylvania Press, 219-255.

Tanret, Michel (1991), The Ur-utu Archive (Mesopotamian History and Environment, Series 3, Texts), Ghent: University of Ghent.

Tessier, Béatrice (1994), Sealing and Seals on Texts from Kültepe kārum Level 2 (Publications de l'Institut historique-archéologique néerlandais de Stamboul 70), Istanbul: Nederlands Historisch-Archaeologisch Instituut te Istanbul.

Van Lerberghe, Karel (2003), 'Private and public: The Ur-Utu archive at Sippar-Ammanum (Tell ed-Der)', in Maria Brosius (ed.) 2003, 59-77.

Veenhof, Klaas R. (ed.) (1986), 'Cuneiform Archives. An Introduction', in Klaas R. Veenhof (ed.), Cuneiform Archives and Libraries, Papers read the 30e Rencontre Assyriologique Internationale Leiden, 4-8 July 1983 (Publications se l'Institut historique-archéologique néerlandais de Stamboul 57), Leiden: Nederlands Instituut voor het Nabije Oosten, 1-36.

Veenhof, Klaas R. (1987), “'Dying Tablets” and “Hungry Siver”... Elements of Figurative Language in Akkadian Commercial Terminology', in Murray Mindlin, Markham J. Geller and John E. Wansbrough (eds), Figurative Language in the Ancient Near East, London: University of London, School of Oriental and African Studies, 41-75.

Veenhof, Klaas R. (2003a), 'Archives of Old Assyrian Traders', in Maria Brosius (ed.) 2003, 78123.

Veenhof, Klaas R. (2003b), 'Trade and Politics in Ancient Assur. Balancing of Public, Colonial and Entrepreneurial Interests', in Carlo Zaccagnini (ed.), Mercanti et Politica nel Mondo Antico (Saggi di Storia Antica 21), Rome: L’Erma di Bretschneider, 69-118.

Veenhof, Klaas R. (2005), Letters in the Louvre (Altbabylonische Briefe 14), Leiden-Boston: Brill.

Veenhof, Klaas R. (2008), 'Communication in the Old Assyrian Trading Society by Caravans, Travelers and Messengers', in Cécile Michel (ed.), Old Assyrian Studies in Memory of Paul Garelli (Old Assyrian Archives Studies 4, Publications de l'Institut historique-archéologique néerlandais de Stamboul 112), Leiden: Nederlands Instituut voor het Nabije Oosten, 199-246.

Veenhof, Klaas R. (2010), (Ankara) Kültepe Tabletleri V. The Archive of Kuliya, son of Ali-abum (Kt 92/k 188-263) (Türk Tarih Kurumu Yayınları VI/33c), Ankara: Türk Tarih Kurumu Basimevi.

Veenhof, Klaas R. (2013a), 'The Archives of Old Assyrian Traders: their Nature, Functions and Use', in Michele Faraguna (ed.) 2013, 27-71.

Veenhof, Klaas R. (2013b), 'New Mesopotamian Treaties from the Early Second Millennium BC from kārum Kanesh and Tell Leilan (Šehna)', in Zeitschrift für Altorientalische und Biblische Rechtsgeschichte, 19, 23-57.

Veenhof, Klaas R. (2015), 'The Archive of Elamma son of Iddin-Suen and his Family', in Fikri Kulakoğlu and Cécile Michel (eds), Proceedings of the $1^{\text {st }}$ Kültepe International Meeting, Kültepe, 19-23 September 2013. Studies dedicated to Kutlu Emre (Kültepe International Meeting 1, Subartu XXXV), Turnhout: Brepols, 73-83.

Veenhof, Klaas R. (in press), (Ankara) Kültepe Tabletleri V. The Archive of Elamma, son of IddinSuen (Kt 91/k) (Türk Tarih Kurumu Yayınları VI), Ankara: Türk Tarih Kurumu Basimevï. 